\title{
Consequences of Duchenne Muscular Dystrophy in Gastrointestinal Tract
}

\author{
Mariana Cruz Lazzarin and Flavia de Oliveira* \\ Department of Biosciences, Federal University of Sao Paulo, Brazil
}

Submission: September 09, 2017; Published: August 22, 2018

"Corresponding author: Flavia de Oliveira, Department of Biosciences, Federal University of Sao Paulo, UNIFESP, Rua Silva Jardim, 136-Lab 328, CEP: 11015-020, Santos-SP, Brazil, Fax: +55 13 3229-0244; Email: flavia_de_o@yahoo.com.br; flavia.oliveira@unifesp.br

\begin{abstract}
Duchenne Muscular Dystrophy (DMD) is the neuromuscular disorder caused by mutations in the gene encoding dystrophin protein, which connects the cytoskeleton with the extracellular matrix of skeletal muscle. Visceral smooth muscle cells contain the same levels of dystrophin, consequently, it can be associated to absence of dystrophin in smooth muscle with degeneration of gastrointestinal (GI) tract. Complications related to GI tract are common in DMD, and include chronic constipation, gastro-esophageal reflux, delayed gastric emptying, swallowing impairment, collection of gastric air and heartburn. Although studies have been associated gastrointestinal dysfunctions in DMD to absence of dystrophin in smooth muscle, in mice models, alterations of the enteric nervous system it has also been suggested. In general, the enteric nervous system to determinate gastrointestinal motility and regulates local blood flow, interacts with the endocrine and immune systems of the intestine. Advances in studies that consider the disease a mix of smooth muscle and enteric nervous system impairments are required to future breakthrough in the pharmacological interventions to restore normal motor function of GI tract and improve the quality of life in DMD patients.
\end{abstract}

Keywords: Dystrophin; Smooth muscle; Enteric nervous system; Gastrointestinal tract

Abbreviations: DMD: Duchenne Muscular Dystrophy; GI: Gastrointestinal; NOS: Nitric Oxide Synthase; DAPC: Dystrophin-Associated Protein Complex

\section{Introduction}

Duchenne Muscular Dystrophy (DMD) is the neuromuscular disorder, affecting approximately 1 in 3700-10.000 newborn males [1]. This disorder is caused by mutations in the gene encoding dystrophin protein, which connects the cytoskeleton with the extracellular matrix of muscle [2]. The absence of dystrophin leads to progressive skeletal muscle wasting associated with increased inflammation, oxidative stress, Ca2+ influx and loss of nitric oxide synthase (NOS) function [3]. DMD is a multi-systemic disease because affects skeletal muscle, heart, brain and smooth muscles, due to expression of dystrophin in these organs [4].

Dystrophin is a component of the dystrophin-associated protein complex (DAPC) localized in sarcolemma of skeletal, cardiac and smooth muscular fibers. Visceral smooth muscle cells contain the same levels of dystrophin comparable to those found in striate muscle cells [5]. Consequently, it can be associated to absence of dystrophin in smooth muscle with degeneration of gastrointestinal (GI) muscles [6] and disturbances in the GI tract [7]. Due to dystrophin expression in smooth muscle, visceral defects are a primary manifestation of dystrophyn deficiency in smooth muscle [5]. Because of this, gastric dilatation and intestinal pseudoobstruction [8] may occur and the complications related to GI tract are common in DMD, and include chronic constipation, gastro-esophageal reflux, delayed gastric emptying, swallowing impairment, collection of gastric air $[9,10]$ and heartburn [11].

According to Boland et al. [8], smooth muscle failure of the gastrointestinal tract is characterized by abdominal pain, vomiting or dysphagia associated to dilatation/dysfunction of digestive tract in the absence of fecal impaction or structural cause of digestive obstruction. The same authors consider gastrointestinal involvement occurs most commonly as "secondary" events in DMD, for example, caused post-surgery or bouts of respiratory distress or pain.

Dysphagia has been found to be the most frequently reported symptom in DMD because impaired function of the pharynx and oesophagus. Both the upper part of oesophagus (striated muscle) and the lower (smooth muscle) are affected by dystrophyn deficience and the amplitude of the contraction waves and coordination of swallow are also affected and 
sometimes resulting in aspiration [7]. Already chronic intestinal pseudoobstruction is characterized by ineffective intestinal peristalsis like mechanical obstruction. Chronic intestinal pseudoobstruction is characterized by ineffective intestinal peristalsis, producing a clinical picture indistinguishable from true mechanical obstruction and may be produced by abnormalities of the intestinal smooth muscle or myenteric plexus [7]. However, according to Rönnblom \& Danielsson [12], diarrhoea is more common due to bile acid malabsorption, smallbowel bacterial overgrowth and reduced levels of pancreatic isoamylase and collagenous sprue.

All cited gastrointestinal problems might lead to nutritional problems with advancing age in DMD patients [13]. Undernutrition and weight loss are common in patients with DMD in their late teens and require adequate nutrition and medication therapy to alleviate symptoms [9]. These patients in long-term ventilation demonstrate metabolic acidosis related to chronic constipation and nutritional monitoring is essential in this stage [10].

Although studies have been associated gastrointestinal dysfunctions in DMD to absence of dystrophin in smooth muscle, in mice models, alterations of the enteric nervous system it has also been suggested. The human enteric nervous system contains many neurons, approximately 107 to 108 [14] and consists of neurons, glial cells organized in interconnected ganglia and nervous fibers that innervate effectors tissues as smooth muscle in the intestinal wall, epithelial coating, intrinsic blood vessels and endocrine, gastric, and pancreatic cells [15]. Ganglia and nervous fibers form a network in the gastrointestinal tract, constituting a ganglionar plexuses, of which stand out myoenteric plexus and submucosal plexus [16]. Myoenteric plexus is primarily involved in control of the smooth muscle motor pattern (peristalsis), on the other hand, submucosal plexus coordinates secretions and absorption reflexes, as well as motor control of the mucosa smooth muscle [17]. In general, the enteric nervous system to determinate gastrointestinal motility and regulates local blood flow, interacts with the endocrine and immune systems of the intestine [15].

The mdx ( $\mathrm{x}$-chromosome-linked muscular dystrophy) mice are the most commonly employed experimental model in DMD research and has deficiency in the gene responsible for coding dystrophin, as observed in human DMD [18]. Smooth muscles from adult mdx mice showed neither cell necrosis nor fibrosis, but the thickness of the mdx smooth muscle was significantly reduced in the digestive layers $[6,8]$. However, in addition to alterations in smooth muscle in this mice model, modifications of the enteric nervous system have also been reported associated with slow wave activity. Vannucchi et al. [19] indicated that myenteric neurones express several dystrophin isoforms in murine model and its lack might cause the intestinal motor abnormalities reported in DMD patients. In an $\mathrm{mdx}$ mice immunohistochemical study, interstitial cells of Cajal (ICC), enteric neurons, and smooth muscle expressed full-length dystrophin [20]. Ultrastructural evaluation of $\mathrm{mdx}$ mice, all the ICC sub-types underwent important changes: coated vesicles were significantly more numerous and caveolae significantly fewer than in control mice, but the networks were maintained [21]. In the same study, electrical activity investigation shows slow waves in a highly dysrhythmic fashion.

\section{Conclusion}

Previous life expectance of DMD patients was on average 24 years old [22]. In the last twenty years, treatments have been established that have significantly improved patients' quality of life and life expectancy on average 30 and 40 years old [23]. This improve represents a challenge to healthcare multiprotection team because multi-systemic impairment. Especially for gastrointestinal dysfunctions in DMD, advances in studies that consider the disease a mix of smooth muscle and enteric nervous system impairments are required to future breakthrough in the pharmacological interventions to restore normal motor function of GI tract. Finally, the integration between clinical and nutritional care to gastrointestinal dysfunction treatment, are crucial to control secondary DMD systemic diseases and improve the quality of life in DMD patients.

\section{References}

1. Mah JK, Korngut L, Dykeman J, Day L, Pringsheim T, et al. (2014) A systematic review and meta-analysis on the epidemiology of Duchenne and Becker muscular dystrophy. Neuromuscul Disord 24(6): 482-491.

2. Hoffman EP, Brown RH Jr, Kunkel LM (1987) Dystrophin: the protein product of the Duchenne muscular dystrophy locus. Cell 51(6): 919928.

3. Allen DG, Whitehead NP, Froehner SC (2016) Absence of Dystrophin Disrupts Skeletal Muscle Signaling: Roles of $\mathrm{Ca}^{2+}$, Reactive Oxygen Species, and Nitric Oxide in the Development of Muscular Dystrophy. Physiol Rev 96(1): 253-305.

4. Suthar R, Sankhyan N (2017) Duchenne Muscular Dystrophy: A Practice Update. Indian J Pediatr 85(4): 276-281.

5. Hoffman EP, Hudecki MS, Rosenberg PA, Pollina CM, Kunkel LM (1988) Cell and fiber-type distribution of dystrophin. Neuron 1(5): 411-420.

6. Alves GA, Silva LR, Rosa EF, Aboulafia J, Freymüller-Haapalainen E, et al. (2014) Intestine of dystrophic mice presents enhanced contractile resistance to stretching despite morphological impairment. Am J Physiol Gastrointest Liver Physiol 306(3): G191-199.

7. Leon S, Schuffler M, Kettler M, Rohrmann C (1986) Chronic intestinal pseudoobstruction as a complication of Duchenne's muscular dystrophy. Gastroenterology 90(2): 455-459.

8. Boland B, Himpens B, Denef JF, Gillis JM (1995) Site-dependent pathological differences in smooth muscles and skeletal muscles of the adult mdx mouse. Muscle Nerve 18(6): 649-657.

9. Davis J, Samuels E, Mullins L (2015) Nutrition Considerations in Duchenne Muscular Dystrophy Nutr Clin Pract 30(4): 511-521.

10. Lo Cascio CM, Latshang TD, Kohler M, Fehr T, Bloch KE (2014) Severe metabolic acidosis in adult patients with Duchenne muscular dystrophy. Respiration 87(6): 499-503.

11. Jaffe KM, McDonald CM, Ingman E, Haas J (1990) Symptoms of upper gastrointestinal dysfunction in Duchenne muscular dystrophy: casecontrol study. Arch Phys Med Rehabil 71(10): 742-744. 
12. Rönnblom A, Danielsson A (2004) Hereditary muscular diseases and symptoms from the gastrointestinal tract. Scand J Gastroenterol 39(1): $1-4$.

13. Lo Cascio CM, Goetze O, Latshang TD, Bluemel S, Frauenfelder T, et al. (2016) Gastrointestinal Dysfunction in Patients with Duchenne Muscular Dystrophy. PLoS One 11(10): e0163779.

14. Furness JB, Costa M (1980) Types of nerves in enteric nervous system. Neuroscience 5(1): 1-20.

15. Furness JB (2006) The Enteric Nervous System. Malden Mass: Blackwell Publishing.

16. Furness JB (2012) The enteric nervous system and neurogastroenterology. Nat Rev Gastroenterol Hepatol 9(5): 286-294.

17. Phillips RJ, Powley TL (2007) Innervation of the gastrointestinal tract: patterns of aging. Auton Neurosci 136(1-2): 1-19.

18. McGreevy JW, Hakim CH, McIntosh MA, Duan D (2015) Animal models of Duchenne muscular dystrophy: from basic mechanisms to gene therapy. Dis Model Mech 8(3): 195-213.
19. Vannucchi MG, Corsani L, Giovannini MG, Faussone-Pellegrini MS (2001) Expression of dystrophin in the mouse myenteric neurones. Neurosci Lett 300(2): 120-124.

20. Vannucchi MG, Zardo C, Corsani L, Faussone-Pellegrini MS (2002) Interstitial cells of Cajal, enteric neurons, and smooth muscle and myoid cells of the murine gastrointestinal tract express full-length dystrophin. Histochem Cell Biol 118(6): 449-457.

21. Vannucchi MG, Zizzo MG, Zardo C, Pieri L, Serio R, et al. (2004) Ultrastructural changes in the interstitial cells of Cajal and gastric dysrhythmias in mice lacking full-length dystrophin (mdx mice). J Cell Physiol 199(2): 293-309.

22. Jay V, Vajsar J (2001) The dystrophy of Duchenne. Lancet 357(9255): 550-552.

23. Annexstad EJ, Lund-Petersen I, Rasmussen M (2014) Duchenne muscular dystrophy. Tidsskr Nor Laegeforen 134(14): 1361-1364.

\section{Your next submission with JuniperPublishers will reach you the below assets}

- Quality Editorial service

- Swift Peer Review

- Reprints availability

- E-prints Service

- Manuscript Podcast for convenient understanding

- Global attainment for your research

- Manuscript accessibility in different formats

( Pdf, E-pub, Full Text, audio)

- Unceasing customer service

Track the below URL for one-step submission https://juniperpublishers.com/online-submission.php 